\title{
Development of a sensitive enzyme immunoassay (ELISA) for specific identification of Lachesis acrochorda venom
}

Núñez Rangel V (1, 2), Fernández Culma M (1), Rey-Suárez P (1), Pereañez JA (1, 3)

(1) Program of Ophidism and Scorpionism, University of Antioquia, Medellin, Colombia; (2) School of Microbiology, University of Antioquia, Medellin, Colombia; (3) School of Pharmaceutical Chemistry, University of Antioquia, Medellin, Colombia.

\begin{abstract}
The snake genus Lachesis provokes 2 to 3\% of snakebites in Colombia every year. Two Lachesis species, L. acrochorda and L. muta, share habitats with snakes from another genus, namely Bothrops asper and B. atrox. Lachesis venom causes systemic and local effects such as swelling, hemorrhaging, myonecrosis, hemostatic disorders and nephrotoxic symptoms similar to those induced by Bothrops, Portidium and Bothriechis bites. Bothrops antivenoms neutralize a variety of Lachesis venom toxins. However, these products are unable to avoid coagulation problems provoked by Lachesis snakebites. Thus, it is important to ascertain whether the envenomation was caused by a Bothrops or Lachesis snake. The present study found enzyme linked immunosorbent assay (ELISA) efficient for detecting Lachesis acrochorda venom in a concentration range of 3.9 to $1000 \mathrm{ng} / \mathrm{mL}$, which did not show a cross-reaction with Bothrops, Portidium, Botriechis and Crotalus venoms. Furthermore, one fraction of $L$. acrochorda venom that did not show crossreactivity with $B$. asper venom was isolated using the same ELISA antibodies; some of its proteins were identified including one Gal-specific lectin and one metalloproteinase. This test may be useful to physicians, since it could be applicable for tracking the kinetic distribution of antigens in patients or experimentally envenomed animals.
\end{abstract}

Key words: snake venom, Lachesis, Lachesis acrochorda, enzyme-linked immunosorbent assay.

\section{INTRODUCTION}

Snakebite is a common and frequently devastating environmental and occupational pathology, especially in rural areas of tropical developing countries (1). According to the National Health Institute of Colombia, 3405 snakebite cases occurred in the country during 2009, of which $3.2 \%$ were induced by Verrugoso (Lachesis spp.) (2).

The genus Lachesis is unique among New World vipers in having a high number of ventral, dorsal, and cephalic scales, and in laying eggs (3). Lachesis spp. are found preferentially in primary forests and comprise four species: $L$. stenophrys, distributed in lower Central America in the Atlantic lowlands of central and possibly southern Nicaragua through northern Costa Rica to about central Panama; L. melanocephala, located in southern Costa Rica and possibly extreme western Panama, where it is restricted to the Pacific versant; L. acrochorda, distributed in both the Atlantic and Pacific versants of western Panama and into northwestern Colombia on the Atlantic coast where it extends southward into the Cauca and Magdalena river Valleys, and along the Pacific versant of Colombia into northwestern Ecuador; and L. muta, found in South America east of the Andes (3).

Envenomations by Lachesis spp. are characterized by severe coagulopathy with fibrinogen depletion, edema, hemorrhaging, pain and necrosis which may result in permanent sequelae or even death (4). These symptoms 
are very similar to those of Bothrops asper and $B$. atrox, whereas such distinctive symptoms as profuse sweating, nausea, vomiting, abdominal cramps, diarrhea and hypotension may not be manifested by all victims of Lachesis bites (4-7).

Geographical variation in the venom composition of the different Lachesis species may explain differences in the frequency and type of clinical features observed (8). Lachesis genera are frequently distributed in the same regions inhabited by Bothrops genus (3). The lack of treatment for Lachesis bites is still a health problem in some regions, since some clinical observations suggest that Bothrops antivenoms are not efficacious at neutralizing Lachesis toxins (9). Thus, as reported by Jorge et al. (4), patients bitten by Lachesis muta muta snakes may die or have persistently incoagulable blood after being treated with bothropic/crotalic antivenoms.

Distinguishing between Bothrops and Lachesis bites depends on the identification of the snake or on enzyme immunoassay diagnosis. Enzyme linked immunosorbent assay (ELISA) is a method that has been demonstrated to be efficient for the detection of snake venom $(10,11)$.Thus, the aim of the present study was to develop an enzymatic immunoassay as a basis for immunodiagnostic envenomations caused by Lachesis.

\section{MATERIALS AND METHODS}

\section{Venoms}

Venoms of Lachesis acrochorda (three specimens), Bothrops asper (20 specimens), Porthidium nasutum (ten specimens), Bothriechis schlegelii (ten specimens), and Crotalus durissus cumanensis (five specimens), all from Colombia, were obtained by manual extraction of specimens maintained in captivity at the animal house of the Universidad de Antioquia (Medellin, Colombia). Venoms were centrifuged at $800 \mathrm{~g}$ for 15 minutes, and the supernatants were lyophilized and stored at $-20^{\circ} \mathrm{C}$ until use.

\section{Antibody Production}

One rabbit (female 1.8 to $2 \mathrm{~kg}$ body mass) was subcutaneously (SC) immunized with $1 \mathrm{~mL}$ containing $0.5 \mathrm{mg} / \mathrm{mL}$ of the $L$. acrochorda venom emulsified in complete Freund's adjuvant. After 20 days, the animal was SC injected with $1.0 \mathrm{mg} / \mathrm{mL}$ of venom in incomplete Freund's adjuvant. Two venom boosters of 2.0 and $3.0 \mathrm{mg}$, each diluted in incomplete Freund's adjuvant, were injected at 20-day intervals. Blood was collected from the rabbit one day before immunization (preimmune sera) and ten days after the last booster dose. The serum was separated and stored at $-20^{\circ} \mathrm{C}$ until use.

\section{Antibody Purification}

\section{Affinity purification of rabbit IgG}

Hyperimmune sera produced against $L$. acrochorda venom were used for the purification of rabbit IgG by means of a protein A Sepharose column (Amersham Biosciences AB, Sweden). Three milliliters of rabbit hyperimmunized sera was loaded into the column. The column was washed with $0.12 \mathrm{M} \mathrm{NaCl}, 0.04 \mathrm{M}$ sodium phosphate and $\mathrm{pH} 7.2$ buffer (PBS). The bound protein was eluted with $0.1 \mathrm{M}$ glycine- $\mathrm{HCl}$ buffer, $\mathrm{pH}$ 3.0. The fraction containing total IgG was collected into tubes containing $0.5 \mathrm{M}$ Tris, $\mathrm{pH} 8.8$ (0.5 mL Tris $/ 4 \mathrm{~mL}$ solution). The fraction was dialyzed against $\mathrm{PBS}$, and conserved at $4^{\circ} \mathrm{C}$ until use.

\section{Affinity purification of rabbit IgG anti- $L$. acrochorda without anti-B.asper cross- reactivity}

B. asper venom was coupled to $\mathrm{CNBr}$ activated Sepharose 4B. For this, CNBr-activated Sepharose 4B (Amersham Biosciences $\mathrm{AB}$, Sweden) was incubated overnight at $4^{\circ} \mathrm{C}$ with $B$. asper venom (5 mg/mL gel) dissolved in $1 \mathrm{~mL} 0.1 \mathrm{M} \mathrm{NaHCO}_{3}$, and $0.5 \mathrm{M} \mathrm{NaCl}, \mathrm{pH} 8.3$ (binding buffer). The gel was later treated with $0.2 \mathrm{M}$ glycine and incubated at room temperature for two hours. The gel was washed sequentially with binding buffer and 0.1 $\mathrm{M}$ acetate buffer, $\mathrm{pH}$ 4.0. Ten milliliters of the prepared affinity matrix was suspended in PBS, $\mathrm{pH} 7.2$, and later packed in a chromatography column $(12 \times 1.5 \mathrm{~cm})$. The fraction of total IgG was loaded into the column and washed with PBS. Unbound protein was collected with PBS, $\mathrm{pH}$ 7.2. The fraction was dialyzed against PBS, and conserved at $4^{\circ} \mathrm{C}$ until use.

\section{Affinity purification of specific IgG anti- Lachesis venom}

CNBr-activated Sepharose 4B was incubated overnight at $4^{\circ} \mathrm{C}$ with $L$. acrochorda venom (5 $\mathrm{mg} / \mathrm{mL}$ gel) dissolved in $1 \mathrm{~mL} 0.1 \mathrm{M} \mathrm{NaHCO}_{3}$, and $0.5 \mathrm{M} \mathrm{NaCl}, \mathrm{pH} 8.3$ (binding buffer). The gel 
was later treated with $0.2 \mathrm{M}$ glycine and incubated at room temperature for two hours. The gel was washed sequentially with binding buffer and 0.1 $\mathrm{M}$ acetate buffer, $\mathrm{pH}$ 4.0. Ten milliliters of the prepared affinity matrix was suspended in PBS, $\mathrm{pH}$ 7.2, and later packed in a chromatography column $(12 \times 1.5 \mathrm{~cm})$. Previously obtained unbound protein solution was loaded into the column and washed with PBS. The proteins bound to the column were eluted with $0.1 \mathrm{M}$ glycine- $\mathrm{HCl}$ buffer, $\mathrm{pH}$ 3.0. The bound fraction was collected into tubes containing $0.5 \mathrm{M}$ Tris, pH 8.8 (0.5 mL Tris/4 mL solution). The fraction was dialyzed against distilled water, lyophilized, and conserved at $-20^{\circ} \mathrm{C}$ until use. This fraction was denominated "IgG anti-L. acrochorda - not B. asper".

\section{Biotinylation of IgG anti-L. acrochorda - not B. asper}

Purified IgG anti-L. acrochorda - not $B$. asper was labeled with biotin according to the instructions of the manufacturer (Sigma-Aldrich, USA). Briefly, $2 \mathrm{mg}$ of IgG was diluted in $1 \mathrm{~mL}$ of carbonate buffer, $\mathrm{pH}$ 9.6, and mixed with $100 \mu \mathrm{L}$ of biotin $(2.2 \mathrm{mg} / 1 \mathrm{~mL}$ DMSO). The mixture was incubated at room temperature for four hours. Biotin-IgG conjugate was separated from free biotin by dialysis against PBS.

\section{ELISA}

Plates of 96 wells (Nunc Inc., USA) were coated overnight at $4^{\circ} \mathrm{C}$ with $100 \mu \mathrm{L}$ of $\operatorname{IgG}$ per well at 100 $\mu \mathrm{g} / \mathrm{mL}$. The anti-L. acrochorda - not B. asper was diluted in $50 \mathrm{mM}$ carbonate/bicarbonate buffer, $\mathrm{pH}$ 9.6. The plates were then washed five times with washing buffer (PBS pH 7.2: $0.12 \mathrm{M} \mathrm{NaCl}$, $0.04 \mathrm{M}$ sodium phosphate and $0.05 \%$ tween 20 ). The remaining binding sites were blocked with $\mathrm{PBS} \mathrm{pH} 7.2$, containing bovine serum albumin $1 \%$ for two hours at $37^{\circ} \mathrm{C}(100 \mu \mathrm{L} /$ well $)$. Afterwards, the plates were washed again five times with washing buffer. Next, different concentrations (2 up to $1000 \mathrm{ng} / \mathrm{mL}$ ) of L. acrochorda, B. asper, B. schlegelii and $P$. nasutum venoms in sample buffer (PBS and bovine serum albumin 1\%) were added to the plates $(100 \mu \mathrm{L} /$ well $)$ and incubated for one hour at $37^{\circ} \mathrm{C}$.

Plates were washed five times with washing buffer, and then $100 \mu \mathrm{L} /$ well of biotinylated Ig $\mathrm{G}$ anti-L. acrochorda - not B. asper (diluted in sample buffer 1:100) was added and incubated for one hour at $37^{\circ} \mathrm{C}$. After washing, streptavidine (Sigma, USA) diluted in sample buffer (1:1000) was added and incubated for one hour at $37^{\circ} \mathrm{C}$. Immediately after washing, $100 \mu \mathrm{L} /$ well of ABTS (Sigma, USA) diluted in citrate $0.1 \mathrm{M}, \mathrm{pH} 5.0$, containing $30 \%$ hydrogen peroxide was added and incubated for 30 minutes at $37^{\circ} \mathrm{C}$ while protected from light. Subsequently, the absorbance was obtained at $405 \mathrm{~nm}$ in an ELISA plate reader (Awareness Technology, USA). Serum samples from people not bitten were included as controls. The assay was repeated six times in duplicate.

\section{Affinity Purification of the Specific Fraction from $L$. acrochorda Venom}

CNBr-activated Sepharose 4B was incubated overnight at $4^{\circ} \mathrm{C}$ with IgG anti-L. acrochorda - not B. asper $(5 \mathrm{mg} / \mathrm{mL}$ gel) dissolved in $1 \mathrm{~mL} 0.1 \mathrm{M}$ $\mathrm{NaHCO}_{3}$, and $0.5 \mathrm{M} \mathrm{NaCl}, \mathrm{pH} 8.3$ (binding buffer). The gel was later treated with $0.2 \mathrm{M}$ glycine and incubated at room temperature for two hours. The gel was washed sequentially with binding buffer and $0.1 \mathrm{M}$ acetate buffer, $\mathrm{pH}$ 4.0. Ten milliliters of the prepared affinity matrix was suspended in phosphate buffer (0.02 M PBS pH 7.2) and later packed in a chromatography column $(12 \times 1.5$ $\mathrm{cm})$. The venom of $L$. acrochorda $(20 \mathrm{mg} / 2 \mathrm{~mL})$ was loaded in the column and washed with PBS. Proteins bound to column were eluted with of 0.1 $\mathrm{M}$ glycine- $\mathrm{HCl}$, buffer $\mathrm{pH}$ 3.0. The bound fraction was collected into tubes containing $0.5 \mathrm{M}$ Tris $\mathrm{pH}$ 8.8 (0.5 mL Tris/4 mL solution). The fraction was dialyzed against distillated water, lyophilized, and conserved at $-20^{\circ} \mathrm{C}$ until use. This fraction was denominated " $L$. achrochorda specific fraction" (LaSF).

\section{Electrophoresis - SDS PAGE}

The whole venoms or the fraction LaSF was analyzed by SDS-polyacrylamide gel electrophoresis (SDS-PAGE) using 12\% acrylamide gels (12). Respective samples of $40 \mu \mathrm{g}$ were separated under non-reducing conditions and the gels were stained with Coomassie brilliant blue R-250. Molecular weight markers were run in parallel.

\section{RP-HPLC Fractionation and Characterization of the Fraction La-SF}

Two milligrams of the fraction La-SF was dissolved in $200 \mu \mathrm{L}$ of $0.1 \%$ trifluoroacetic acid (TFA), centrifuged for five minutes at 13,000 
rpm, and loaded into a $\mathrm{C}_{18}$ column $(250 \times 4.6$ $\mathrm{mm}, 5 \mu \mathrm{m}$ particle; Teknokroma, Spain) using an Agilent 1200 chromatograph (USA). Elution was performed at $1 \mathrm{~mL} /$ minute by applying a gradient towards solution B (acetonitrile, containing 0.1\% TFA) as follows: $5 \% \mathrm{~B}$ for five minutes, $5-15 \% \mathrm{~B}$ for ten minutes, $15-45 \%$ for 60 minutes, and 45 $70 \%$ B for 12 minutes. Absorbance was monitored at $215 \mathrm{~nm}$, and fractions were manually collected and dried in a vacuum centrifuge (Savant, USA) for subsequent characterization.

The major fractions obtained were separated by SDS-PAGE under reducing conditions, using $12 \%$ gels. Protein bands were excised from Coomassie blue R-250-stained gels and subjected to reduction with dithiothreitol and alkylation with iodoacetamide. This was followed by in-gel digestion with sequencing grade bovine trypsin on an automated processor (ProGest Digilab, USA), according to the manufacturer's instructions. The resulting peptide mixtures were analyzed by MALDI-TOF-TOF mass spectrometry on an Applied Biosystems 4800-Plus instrument (USA). The resulting spectra were analyzed using ProteinPilot v.4 (ABSciex, USA) to identify proteins using the UniProt/SwissProt database (20100622) and the Paragon ${ }^{\varpi}$ algorithm method, at a confidence level of $99 \%$.

\section{Statistical Analysis}

The data were subject to non-parametric statistical analysis. Results are presented as mean \pm standard error. Significant differences between observed absorbance values of L. acrochorda and other venoms were determined by the KruskalWallis test. A Mann-Whitney $U$ test was used to determine the detection limit by comparing absorbances at each concentration of all venoms. Differences were considered significant at $\mathrm{p}<$ 0.05 .

\section{RESULTS}

The anti-L. acrochorda IgG purified by several affinity chromatography steps was highly specific. The sandwich ELISA reactivities for known concentrations of $L$. acrochorda, B. asper, B. schlegelii and $P$. nasutum whole venoms are shown in Figure 1. Concentrations of $2.0 \mathrm{ng} / \mathrm{mL}$ of $L$. acrochorda venom gave measurable absorbance signals. No cross-reactivity was observed with other venoms evaluated in the concentration range of 3.9 to $1000 \mathrm{ng} / \mathrm{mL}$. ( $p \leq 0.01)$. Similar results were observed using $B$. atrox and $C$. d. cumanensis venoms (data not shown). Higher quantities of $L$. acrochorda venoms produced dose-dependent absorbance values. Similar results were obtained when known concentrations of Lachesis venom were put in pooled human serum from healthy individuals (data not shown).

Additionally, the specific IgG used in the ELISA was employed in affinity chromatography to isolate specific components of $L$. acrochorda venom that displayed no cross-reactivity with $B$. asper venom. SDS-PAGE under non-reducing conditions of the obtained fraction denominated LaSF showed three bands, one major at $\sim 29 \mathrm{kDa}$ and two minor bandsat $28 \mathrm{kDa}$ and $14 \mathrm{kDa}$ (Figure 2). Nevertheless, under reducing conditions the major band disappeared and the intensity of the $14 \mathrm{kDa}$ band increased, indicating that the

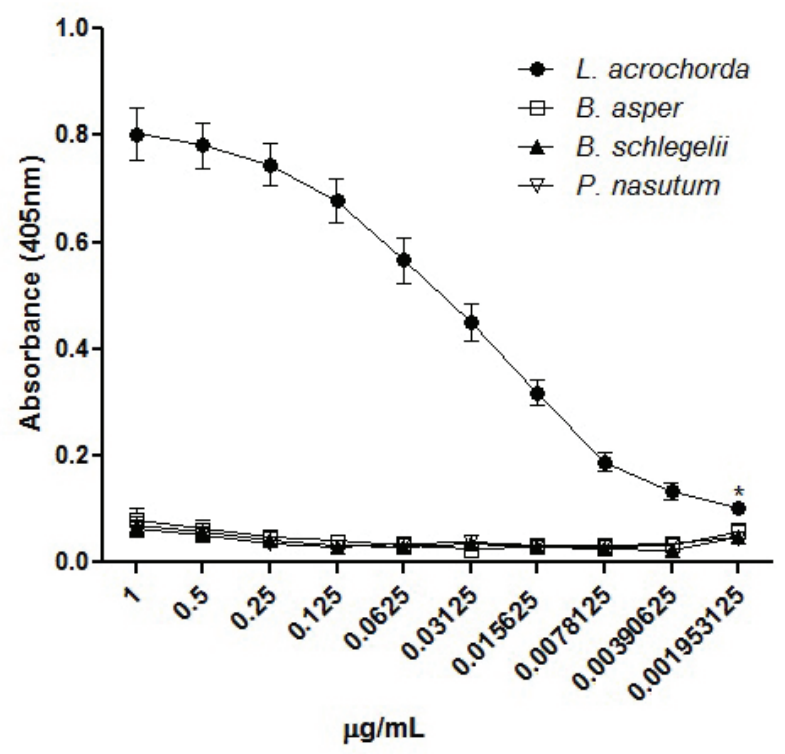

Figure 1. Sandwich-ELISA titration of L. acrochorda, B. asper, B. schlegelii and P. nasutum Colombian snake venoms: 96-well plates were coated with IgG specific anti-L. acrochorda previously obtained by several procedures of affinity chromatography with hyperimmune rabbit serum. The plates were incubated with varying amounts of $L$. acrochorda $(\bullet)$, B. asper ( $\square)$, B. schlegelii $(\mathbf{\Delta})$ and $P$. nasutum $(\nabla)$ venom. Biotinylated anti-L. acrochorda lgG was added and incubated. These values are the average of six experiments, performed in duplicate, \pm SE. Assay details are described in the Materials and Methods section. 


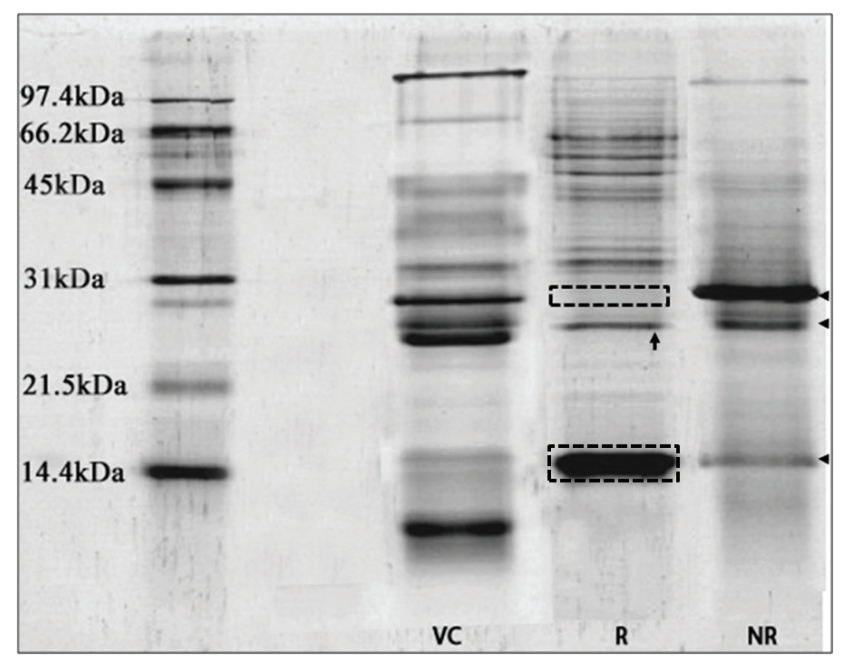

Figure 2. SDS-polyacrylamide gel electrophoresis. VC: whole venom. NR: specific fraction of $L$. acrochorda (LaSF) isolated using IgG anti-L. acrochorda - not B. asper in non-reducing conditions. R: LaSF in reducing conditions. Arrows show the main proteins observed in the fraction (29, 28 and $14 \mathrm{kDa}$ ). The rectangles show changes in 29 $\mathrm{kDa}$ protein, which disappears while augmenting the $14 \mathrm{kDa}$ band in reducing conditions. Molecular mass markers (Biorad, USA) are shown on the left. protein is a dimer. Similarly, the separation of $\mathrm{La}$ SF by RP-HPLC showed two major peaks (Figure 3). Four peptides - YGESLEIAEYISDYHK, EFCVELVSLTGYR, DFSWEWTDR and YGESLEIAEYISDYHKGQAEVWIGLWDK obtained from the major peak corresponded to Gal-specific lectin, while the minor peak was identified as metalloproteinases (VHEIVNFINGFYR, YIELVVVADHGM ${ }_{\text {ox }}$ FTK, NSVGIVQDHSPK and YNGNLNTIR).

\section{DISCUSSION}

Antibodies against specific components are important tools for establishing venom detection immunoassays useful in snakebite diagnosis (13). The identification of the snake involved in the accident allows selection of the correct specific antivenom. In the present work, the anti-L. acrochorda IgG purified by several affinity chromatography steps was highly specific and may be important in the development of diagnostic kits to differentiate among envenomations caused by $L$. acrochorda and B. asper/atrox, P. nasutum, and $B$. schlegelii, the species responsible for most snakebites in Colombia. In addition, this highly specific IgG may contribute to epidemiological

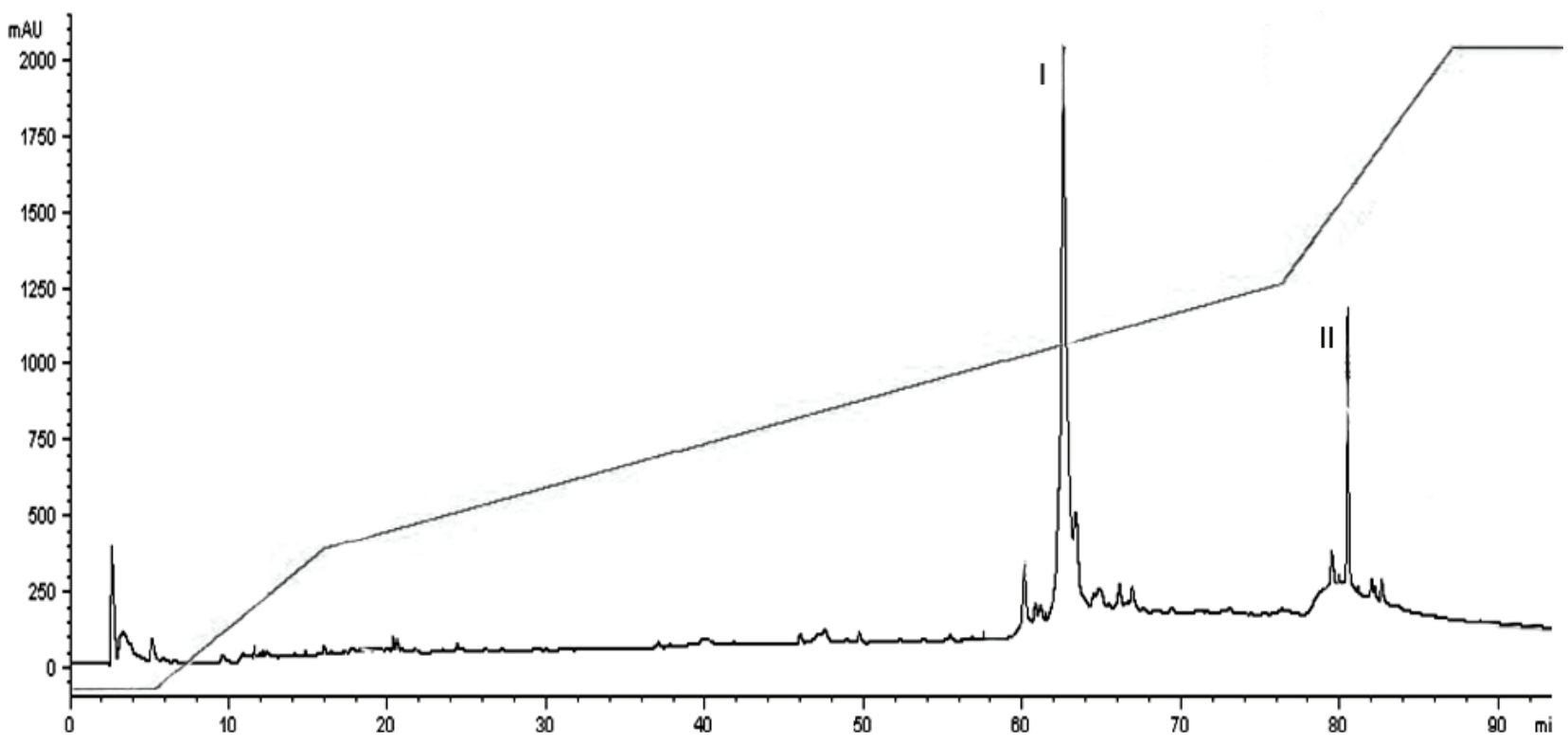

Figure 3. Reverse HPLC of LaSF (Lachesis acrochorda specific fraction). Fraction LaSF was loaded into a $\mathrm{C}_{18}$ column using an Agilent 1200 chromatograph (USA). Elution was performed at $1 \mathrm{~mL} /$ minute by applying acetonitrile gradient containing $0.1 \%$ TFA. Absorbance was monitored at $215 \mathrm{~nm}$; fractions were manually collected and dried in a vacuum centrifuge (Savant, USA). Peak I was identified as a Gal-specific lectin and peak II as a metalloproteinase. 
statistics by assessing the number and geographical distribution of ophidian accidents.

Colombini et al. (14) showed considerable antigenic cross-reactivity between $B$. asper/atrox and Lachesis venoms. However, they showed by using species-specific monoclonal antibodies that some molecules were particular to $L . m$. muta venom in some regions. Several proteins had been reported from Lachesis species such as a lectin-like dimer protein, with molecular mass of $28 \mathrm{kDa}$, isolated from L. muta venom (15). An acidic kininogenin from Lachesis muta venom was purified and shown to be a highly stable serine protease with a molecular mass of 27.9 $\mathrm{kDa}$, and capable of releasing bradykinin from bovine kininogen (16). Giovanni-de-Simone et al. (17) isolated a kalikrein-like protein from Lachesis muta rhombeata from Brazil with a molecular mass of $32 \mathrm{kDa}$. Several reports about phospholipases $\mathrm{A}_{2}$ have been published (18-20). Sanchez et al. (21) identified a serine proteinase of $33 \mathrm{kDa}$, denoted LV-PA, from Lachesis muta muta venom; this toxin selectively converts plasminogen into plasmin in vitro. LV-PA, detected at the rate of $1.5 \mathrm{ng}$ of venom per assay, was used to develop a specific ELISA to detect Lachesis muta muta venom (13).

In the present work the specific IgG used in the ELISA was employed in affinity chromatography to isolate a specific fraction of Lachesis acrochorda venom that did not cross-react with $B$. asper venom (i.e. $L a S F$ ). The main components present in this fraction were identified as a lectin and a metalloproteinase.

One study on Lachesis species from Costa Rica, Brazil and Colombia found some significant differences in the pharmacological activities induced by their venoms (22). However, there was not a consistent variation pattern in those activities. Furthermore, subtle variations in the electrophoretic patterns of the venoms were observed. A recent study to develop a proteomic characterization of venoms of $L$. muta from Brazil and L. stenophrys from Costa Rica revealed that these venoms share (or contain highly similar) proteins, in particular bradykinin-potentiating/ C-natriuretic peptide (BPPs), serine proteinases, a galactose-specific C-type lectin, and L-amino acid oxidase (LAO). However, they dramatically differ in their respective PLA 2 complement (23).

Various immunological methods have been reported for detecting Lachesis venom, but
Lachesis acrochorda has not been included (11, 13, 24). And as previously mentioned, some differences among Lachesis species had been observed (23). Furthermore, geographical variations in the venom components demand the development of regional immunodiagnostic tests specific to snakes that inhabit a given region (25). Thus, this ELISA assay may contribute to improving the diagnosis and treatment of snakebites in Colombia. Finally, the LaSF fraction could be used in the immunization mixture for the production of polyvalent antivenom in Colombia.

\section{ACKNOWLEDGEMENTS}

The authors thank Prof. Bruno Lomonte (Instituto Clodomiro Picado, Costa Rica) for identification of peaks of Lachesis acrochorda venom ( $\mathrm{LaSF}$ ).

\section{COPYRIGHT \\ (C) CEVAP 2012}

\section{SUBMISSION STATUS}

Received: September 8, 2011.

Accepted: December 20, 2011.

Abstract published online: January 25, 2012.

Full paper published online: May 31, 2012.

\section{CONFLICTS OF INTEREST}

The authors declare that there are no conflicts of interest.

\section{FINANCIAL SOURCE}

Universidad de Antioquia (CODI project), and COLCIENCIAS (project 1115-459-21441 and Programa de Jóvenes Investigadores) provided the financial grants for this project.

\section{ETHICS COMMITTEE APPROVAL}

The present study was approved by the Ethics Committee of Antioquia University, Medellin, Colombia.

\section{CORRESPONDENCE TO}

Vitelbina Nuñez Rangel, Programa de Ofidismo/ Escorpionismo, Universidad de Antioquia, Medellín, Colombia. Phone: 57421965 35. Email: vitelbina.nunez@siu.udea.edu.co.

\section{REFERENCES}

1. Warrell DA. Snake bite. Lancet. 2010;375(9708):77-88.

2. Heredia M. Informe anual de accidente ofídico. 
Instituto Nacional de Salud. Colombia: SIVIGILA Subdirección de Vigilancia y Control en Salud Pública; 2009.

3. Campbell JA, Lamar WW. The venomous reptiles of the western hemisphere. Ithaca, NY: Cornell University Press; 2004. 436-47 p.

4. Jorge MT, Sano-Martins IS, Tomy SC, Castro SC, Ferrari RA, Ribeiro LA, et al. Snakebite by the bushmaster (Lachesis muta) in Brazil: case report and review of the literature. Toxicon. 1997;35(4):545-54.

5. Silva J. Accidentes humanos por las serpientes de los géneros Bothrops y Lachesis. Mem Inst Butantan. 1980/81;44-5:403-23.

6. Bolaños R, Rojas O, Ulloa Flores CE. Biomedical aspects of 4 cases of snake bites by Lachesis muta (Ophidia: Viperidae) in Costa Rica. Rev Biol Trop. 1982;30(1):53-8.

7. Otero R, Tobón GS, Gómez LF, Osorio RG, Valderrama R. Bites from the bushmaster (Lachesis muta) in Antioquia and Chocó, Colombia. Report of five accidents. Toxicon. 1993;31(2):158-9.

8. Pardal PP, Sousa SM, Monteiro MR, Fan HW, Cardoso JL, França FO, et al. Clinical trial of two antivenoms for treatment of Bothrops and Lachesis bites in the north Eastern Amazon region of Brazil. Trans R Soc Trop Med Hyg. 2004;98(1):28-42.

9. Bard R, de Lima JC, de Sa Neto RP, de Oliveira SG, dos Santos MC. Inefficacy of bothropic antivenin in the neutralization of the coagulation activity of Lachesis muta muta venom. Report of a case and experimental confirmation. Rev Inst Med Trop São Paulo. 1994;36(1):77-81.

10. Theakston RD. The application of immunoassay techniques, including enzyme-linked immunosorbent assay (ELISA), to snake venom research. Toxicon. 1983;21(3):341-52.

11. Chavez-Olortegui C, Lopes CS, Cordeiro FD, Granier C, Diniz CR. An enzyme linked immunosorbent assay (ELISA) that discriminates between Bothrops atrox and Lachesis muta muta venoms. Toxicon. 1993;31(4):417-5.

12. Laemmli UK. Cleavage of structural proteins during the assembly of the head of bacteriophage T4. Nature. 1970;227(5259):680-5.

13. Felicori LF, Chavez-Olortegui C, Sánchez EF. Specific identification of Lachesis muta muta snake venom using antibodies against the plasminogen activator enzyme, LV-PA. Toxicon. 2005;45(6):803-06.

14. Colombini M, Fernandes I, Cardoso DF, Moura-daSilva AM. Lachesis muta muta venom: immunological differences compared with Bothrops atrox venom and importance of specific antivenom therapy. Toxicon. 2001;39(5):711-9.
15. Aragón-Ortíz F, Brenes-Brenes JR, Gubensek F. Characterization of a lectin-like protein isolated from Lachesis muta snake venom. Rev Biol Trop. 1989;37(1):79-83.

16. Diniz MR, Oliveira EB. Purification and properties of a kininogenin from the venom of Lachesis muta (bushmaster). Toxicon. 1992;30(3):247-58.

17. Giovanni-de-Simone S, Aguiar AS, Gimenez AR, Novellino K, de Moura RS. Purification, properties, and $\mathrm{N}$-terminal amino acid sequence of a kallikrein-like enzyme from the venom of Lachesis muta rhombeata (Bushmaster). J Protein Chem. 1997;16(8):809-18.

18. Fuly AL, Machado OL, Alves EW, Carlini CR. Mechanism of inhibitory action on platelet activation of a phospholipase $\mathrm{A}_{2}$ isolated from Lachesis muta (Bushmaster) snake venom. Thromb Haemost. 1997;78(5):1372-80.

19. Fuly AL, de Miranda AL, Zingali RB, Guimarăes JA. Purification and characterization of a phospholipase $\mathrm{A}_{2}$ isoenzyme isolated from Lachesis muta snake venoms. Biochem Pharmacol. 2002;63(9):1589-97.

20. Damico DC, Lilla S, de Nucci G, Ponce-Soto LA, Winck FV, Novello JC, et al. Biochemical and enzymatic characterization of two basic Asp49 phospholipase $\mathrm{A}_{2}$ isoforms from Lachesis muta muta (Surucucu) venom. Biochim Biophys Acta. 2005;1726(1):75-86.

21. Sanchez EF, Santos CI, Magalhaes A, Diniz CR, Figueiredo S, Gilroy J, et al. Isolation of a proteinase with plasminogen-activating activity from Lachesis muta muta (Bushmaster) snake venom. Arch Biochem Biophys. 2000;378(1):131-41.

22. Otero R, Furtado MF, Gonçalves C, Núñez V, García ME, Osorio RG, et al. Comparative study of the venoms of three subspecies of Lachesis muta (bushmaster) from Brazil, Colombia and Costa Rica. Toxicon. 1998;36(12): 2021-7.

23. Sanz L, Escolano J, Ferretti M, Biscoglio MJ, Rivera E, Crescenti EJ, et al. Snake venomics of the South and Central American Bushmasters. Comparison of the toxin composition of Lachesis muta gathered from proteomic versus transcriptomic analysis. J Proteomics. 2008;71(1):46-60.

24. Heneine LG, Catty D. Species-specific detection of venom from snakes of the Bothrops and Lachesis genera. Toxicon. 1993;31(5):591-603.

25. Brunda G, Sashidhar RB, Sarin RK. Use of egg yolk antibody (IgY) as an immunoanalytical tool in the detection of Indian cobra (Naja naja naja) venom in biological samples of forensic origin. Toxicon. 2006;48(2):183-94. 